\title{
First Report on Bat Mortalities on Wind Farms in Chile
}

\section{Primer reporte de mortalidad de murciélagos en Granjas Eólicas en Chile}

\author{
Luis E. Escobar ${ }^{1,2,3^{*}}$, César Juarez ${ }^{2}$, Gonzalo Medina-Vogel ${ }^{1}$ \& Carlos M. Gonzalez ${ }^{1}$ \\ ${ }^{1}$ Facultad de Ecología y Recursos Naturales, Universidad Andres Bello, República 440, Santiago, Chile \\ 2Programa para la Conservación de los Murciélagos de Chile, Los Alerces 3024, Ñuñoa, Chile \\ ${ }^{3}$ Center for Global Health and Translational Science, State University of New York Upstate Medical University, Syracuse, New \\ York, USA \\ *ecoguate2003@gmail.com, Phone: +1 315 464-8153
}

\begin{abstract}
In Latin America there is a lack of scientific reports of bat mortality caused by wind farms operation. We report for the first time, clear evidence of bat mortalities from wind farms in Chile. We generated an ecological niche model of the affected species, Tadarida brasiliensis, to explore areas of potential species distribution overlapping with areas with distribution of wind farms in Chile. We found that T. brasiliensis potential distribution overlaps with the current and future distribution of wind farms in Chile. Rapid developments are currently being made within the wind energy industry in Chile. Future research should quantify the impact patterns of wind farms on wildlife, explore mitigation methods, and determine the areas with high biodiversity vulnerability in Chile.
\end{abstract}

KeYwords: Bat, ecological niche model, Tadarida brasiliensis, wind-powered turbines.

\section{RESUMEN}

En América Latina hay una falta de reportes científicos sobre la mortalidad en murciélagos causada por la operación de granjas eólicas. Reportamos por primera vez evidencia clara de la mortalidad de murciélagos causada por granjas eólicas en Chile. Generamos un modelo de nicho ecológico para la especie afectada, Tadarida brasiliensis, con el fin de explorar la coincidencia entre las áreas de distribución potencial de la especie y la distribución de granjas eólicas en Chile. Encontramos que la distribución potencial de T. brasiliensis traslapa con la distribución actual y futura de granjas eólicas en Chile. En Chile existe un rápido desarrollo de la industria eólica. Futura investigación debe procurar cuantificar el impacto de las granjas eólicas sobre la vida silvestre, explorar métodos de mitigación y determinar las áreas con alta vulnerabilidad para la biodiversidad en Chile.

Palabras clave: Granja eólica, modelo de nicho ecológico, mortalidad de murciélagos, Tadarida brasiliensis.

\section{INTRODUCTION}

Wind-powered turbines (wind farms) have a strong link with bird and bat mortalities (Kuvlesky et al. 2007). Several studies from Europe and North America show seasonality and species specificity in bat mortality rates (Kuvlesky et al. 2007). Bat collisions with turbines may be non-random and could be related to foraging behavior (Horn et al. 2008). Quantification of bat mortality is based on dead bats numbers by turbine by year and dead bat numbers by energy produced (Cryan \& Barclay 2009; Kuvlesky et al. 2007). Previous articles reported key diagnostic features from dead bats found in wind energy facilities (Rollins et al. 2012; Baerwald et al. 2008). Pulmonary damage and signs of traumatic injury have been the most frequent lesions found in dead bats collected near turbines (Rollins et al. 2012; Baerwald et al. 2008). In the northern hemisphere, field research showed that bat mortality could be ameliorated by limiting turbine operation in days of low-speed wind during the summer and fall (Arnett et al. 2011).

In South America, Chile has one of the greatest increases in wind farm development, but there is currently no reporting on bat mortality rates. Techniques for diagnosis of bat fatalities and mechanisms for reducing their mortality rates have, however, been proposed (Arnett et al. 2013; Arnett et al. 2011). Several hypotheses have not been tested to better understand how to reduce bat mortality rates (Cryan 
\& Barclay 2009). More data is urgently needed to better understand wildlife fatality occurrences and evaluate the consequences. Considering the low reproductive rate of bats (Barclay et al. 2004) and the high mortality rates caused by wind-powered turbines (Kuvlesky et al. 2007), reduction in bat populations is plausible in the long term at least at a local scale.

Bat species from temperate-zones, such as those found in Chile, have lower reproductive rates when compared with tropical species (Barclay et al. 2004). Chile has the lowest number of bat species in Latin America with only 11 bat species distributed along the main part of its territory (Iriarte 2007). In addition, knowledge of their ecology is poor (Iriarte 2007). We describe the forensic finding of three bat carcasses from wind farms in northern Chile and describe the associated growing development of the wind energy industry in the country. An ecological niche model of the affected bat species was developed to describe its patterns of potential distribution. Further steps for continuing and improving research of wind farms and wildlife are proposed.

\section{MATERIALS AND METHODS}

\section{Bat MORTALITIES}

During a spring 2010 survey, three dead bats were found lying at the foot of wind towers of two wind-powered turbines from two wind farms at the coastal area of Coquimbo, northern Chile located at $31.336^{\circ} \mathrm{S}, 71.616^{\circ} \mathrm{W}$ and $31.066^{\circ} \mathrm{S}, 71.616 \mathrm{~W}$, with a capacity of production of 46 and 48 megawatts respectively. The area has a temperature range of 8 to $21^{\circ} \mathrm{C}$ and low precipitation, 137.9 $\mathrm{mm}$ annually. Samples were fixed in formalin and stored separately until analyses were conducted. In July 2012, the fixed samples were sent to the Unit of Comparative Medicine and Pathology, School of Veterinary Medicine at Universidad Andres Bello, Santiago, Chile. In order to detect gross and microscopic morphologic alterations, bats were radiographed, and necropsies were performed with a dissecting microscope. Tissue samples were embedded in paraffin and stained with haematoxylin eosin.

Additionally, to describe the current and future geographic distribution of wind-powered turbines in Chile, we generated a bibliographic review based on official reports from the Chilean service of Environmental Impact Assessment (www.e-seia.cl) in August 2013. A species richness map was generated for Chile using bat geographic ranges according to the IUCN (IUCN 2014).

Finally, we made an ecological niche model (ENM) of the affected species to project a potential distribution map, via establishing the association between environmental variables and in field reports of the species. As environmental variables, we used climate layers at $\sim 19 \mathrm{~km}$ resolution (Hijmans et al. 2005), a principal components analysis was employed to reduce the correlation and number of variables, and for modeling we used the first five new components summarizing $>97 \%$ of the variance (Peterson et al. 2011). Occurrences were searched in online museum databases including Global Biodiversity Facility (http://www.gbif.org/), SpeciesLink (http://splink.cria.org. br/), VertNet (http://www.vertnet.org/), and Arctos, (http:// arctos.database.museum/), occurrences for Chile were collected from literature (Escobar et al. 2013). The model was generated in Maxent software, version 3.3.3.k (Phillips et al. 2006), using the logistic outputs with ten percentile calibration occurrences as the threshold to generate a binary map, with the rest of the parameters as defaults (Elith et al. 2011). The model was evaluated by splitting occurrences in five latitudinal sets, using the first, third, and fifth latitudinal sets as calibration occurrences and second and fourth latitudinal sets as evaluation occurrences (Fig. 1). The model was evaluated using two measurements. The first geographically, using a cumulative binomial test with the number of evaluation occurrences as trials, number of evaluation occurrences predicted correctly as successes, and the proportion of evaluation area predicted as present as probability (Anderson et al. 2002). Then, the model was evaluated environmentally, testing if environmental information from evaluation occurrences was contained in the environments from the calibration occurrences (Fig. 1). Once the predictive capability of the algorithm, the environmental representativeness of occurrences, and the quality of the environmental variables were tested, we generated a final model using all occurrences available, such a model was visualized in the environmental space as the existent niche of the species (Peterson et al. 2011). Spatial analyses were done using ArcGIS 9.3 (ESRI, Redlands, CA, USA), while analyses in the environmental space were developed using NicheA 3.0 (Qiao et al. 2015)

\section{RESULTS}

\section{BAT MORTALITIES}

All three bats examined were female Tadarida brasiliensis. Two of these showed no sign of external injuries. After radiographed only one had skeletal trauma; it was found eviscerated with internal hemorrhages and evident bone fractures. On the other bats, pulmonary hemorrhage was evident, but we failed to identify other macroscopical lesions. Histological examination on bats without bone trauma revealed that these bats had alveolar emphysema (Fig. 2). One of the bats was determined to be pregnant. 

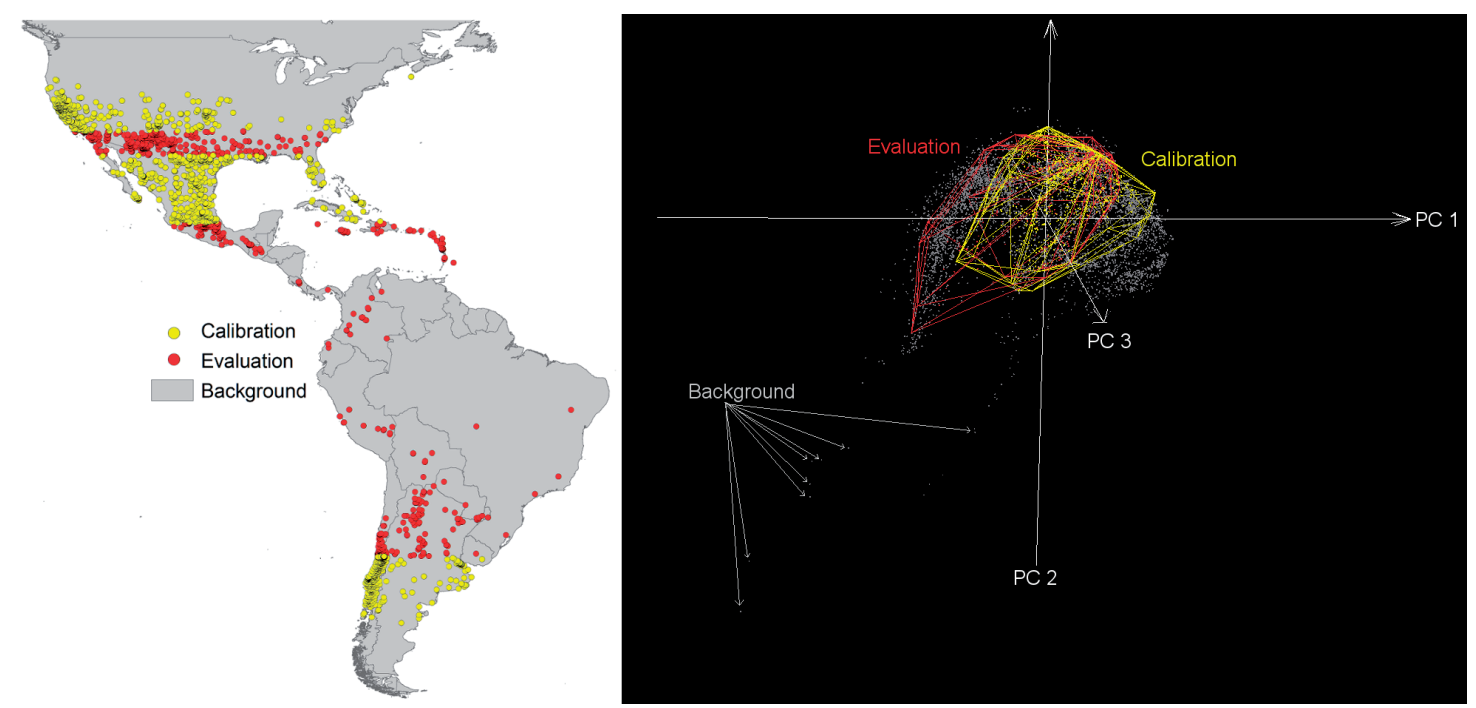

Figure 1. Occurrence of Tadarida brasiliensis. Left: original distribution of occurrences in the geographic space. Occurrences were separated in five latitudinal sets, grouped in calibration (yellow points) and evaluation (red points) used for model test. Environmental values were collected across the Americas (gray area; i.e., background environments). Right: original distribution of occurrences in the geographic space were translated to the environmental space in NicheA, according with their environmental values. Occurrences were grouped in calibration (yellow points and polyhedron) and evaluation (red points and polyhedron) for model evaluation. Arrows show portions of the environmental background (gray points). Axes are the first three principal components from bioclimatic variables.

Figura 1. Ocurrencia de Tadarida brasiliensis. Izquierda: distribución original de las ocurrencias en el espacio geográfico. Para evaluar el modelo, las ocurrencias fueron divididas latitudinalmente en cinco grupos, unos para calibración (puntos amarillos) y otros para evaluación (puntos rojos). Los valores ambientales fueron colectados a lo largo de las Américas (área gris; i.e., ambientes de referencia). Derecha: las ocurrencias distribuidas originalmente en el espacio geográfico fueron transferidas a un espacio ambiental usando NicheA de acuerdo a los datos ambientales individuales. Para evaluar el modelo, las ocurrencias fueron agrupadas en un conjunto para calibración (puntos y poliedro amarillos) y otro para evaluación (puntos y poliedro rojos). Las flechas denotan las porciones de los ambientes que se usaron de referencia (puntos grises). Ejes son los primeros tres componentes a partir de las variables bioclimáticas.

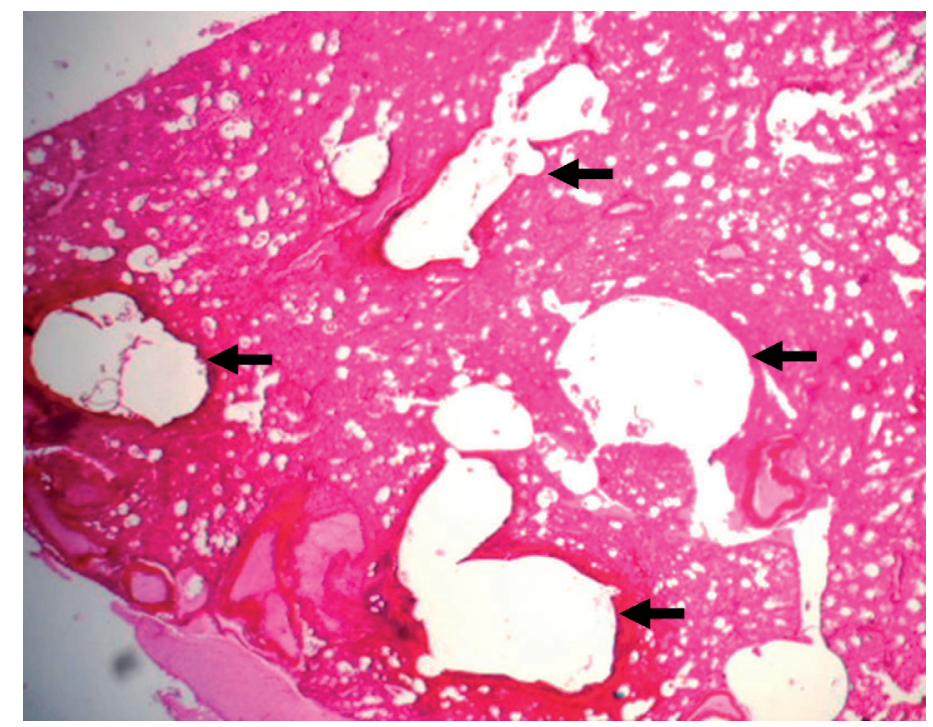

FIGURE 2. Lung tissue section with severe vascular lesions including congestion, edema, hemorrhage, and alveolar emphysema, showing large bullae resulting from alveoli rupture (arrows). Hematoxylin\&Eosine 40x.

FIgURA 2. Parte de tejido pulmonar con severas lesiones vasculares incluyendo congestión, edema, hemorragia y enfisema alveolar, mostrando bullas grandes como resultado de la ruptura alveolar (flechas). Hematoxilina\&Eosina 40x. 


\section{Wind FaRMs IN CHILE}

In 2006, the first wind farm was approved in Chile, and now, several farms are distributed across the country. Since the construction of the first wind-powered turbines in Chile in 2007, another 43 wind farms have been approved, and to date nine new projects are under assessment to be developed in central-south Chile (Fig. 3). Under this scenario more than five wind farms are approved every year; in 2012 alone, fourteen projects were approved.

\section{Wind Farms}

- Approved

$\triangle$ In Evaluation

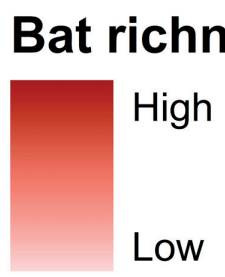

ECOLOGICAL NICHE MODEL

In all, 4303 occurrences were found for $T$. brasiliensis (Fig. 1). During model evaluation, we found that evaluation occurrences had more information than calibration occurrences (i.e., in the environmental space the polyhedron from evaluation occurrences was $22.4 \%$ bigger than the polyhedron from calibration occurrences; Fig. 4). Consequently, 353 evaluation occurrences were not predicted $(20.8 \%$ omission error), but considering the evaluation area, Maxent model predicted evaluation occurrences better than by chance $(P<0.001)$, with $8.8 \times 10^{6} \mathrm{~km}^{2}$ predicted as suitable for the species in the final model (Fig. 4).

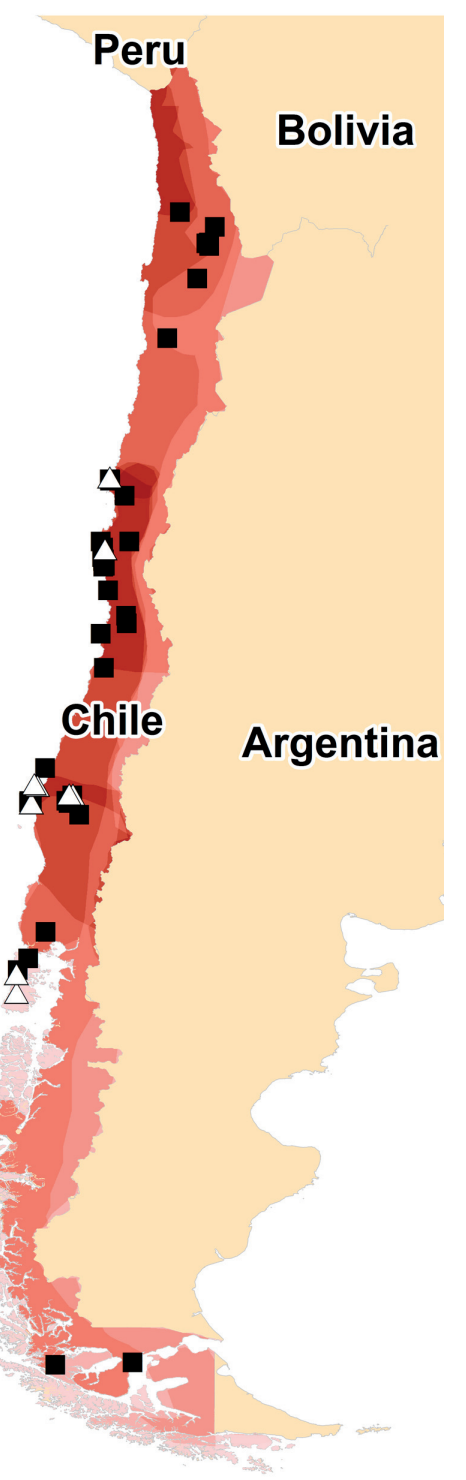

FiguRE 3. Map of current approved wind-farms (black squares) and projects in assessment (white triangles) across Chile, as background bat species richness in Chile (red) according to IUCN 2014.

FiguRA 3. Mapa de las granjas eólicas actualmente aprobadas (cuadros negros) y proyectos en evaluación (triángulos blancos) a lo largo de Chile, como fondo se muestra la riqueza de especies de murciélagos en Chile (rojo) de acuerdo a IUCN 2014. 

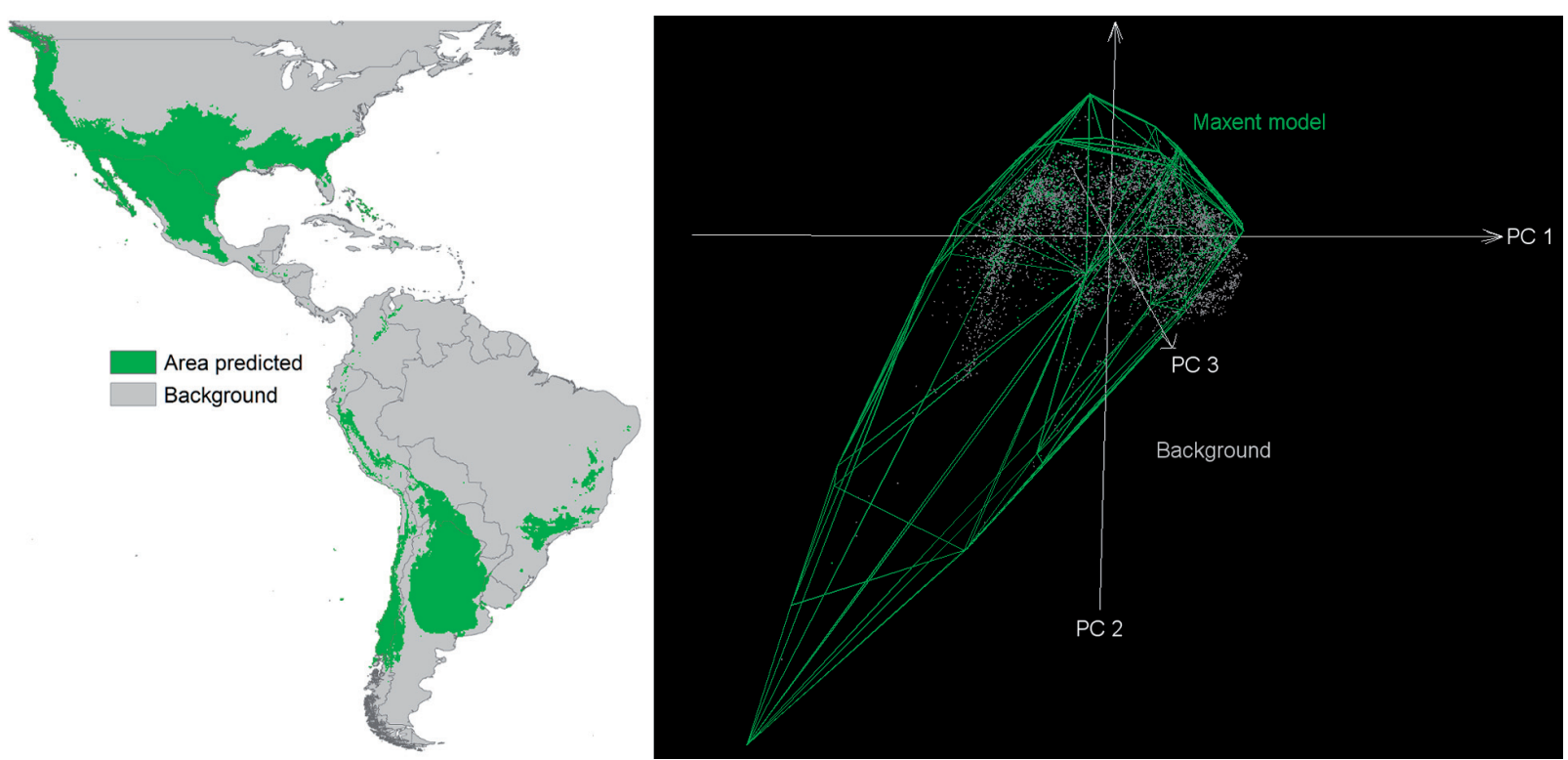

FIGURE 4. Left: potential distribution map for Tadarida brasiliensis (green) based on occurrences from online museum databases and literature with threshold that include $90 \%$ of occurrences. Right: polyhedron of the Maxent model output visualized in the environmental space. Notice that the model included neighbor environmental values from occurrences.

FiguRA 4. Izquierda: mapa de la distribución potencial de Tadarida brasiliensis (verde) basado en las ocurrencias disponibles en línea de bases de datos de museos y literatura, con un punto de corte que incluye el $90 \%$ de las ocurrencias. Derecha: poliedro del resultado de Maxent visto en el espacio ambiental. Note que el modelo incluye valores de ambientes vecinos a las ocurrencias.

\section{DISCUSSION}

Despite having a small number of samples, we found the bat corpses had both macro and microscopic lesions associated with traumas (Fig. 2). Lesions detected in lungs are similar to those previously reported for bat fatalities occurring in wind farms, and they have been associated with barotrauma (Rollins et al. 2012; Baerwald et al. 2008). The term barotrauma is used to describe alveolar overdistension and destruction due to changes in air pressure (Rouby et al. 1993), here associated with the pressure changes made by turbine blades. These lung injuries have been proposed as a cause of bat fatalities in North American wind energy facilities in dead bats without evident injuries (Ellison 2012). Future in vivo experimental research is needed to elucidate the mechanisms associated with pressure changes, acute barotrauma, and bat mortality. Macroscopic lesions (i.e., fractures) can be attributable to collision with the turbine blades (Horn et al. 2008).

Lethal injuries in bats found in wind-powered turbines are not surprising (Horn et al. 2008; Kuvlesky et al. 2007), however this is the first scientific report of bat mortality for wind turbines in Chile. Currently the spread of wind farms in Chile is growing rapidly (Fig. 3), but efforts in environmental assessments are scarce. We encourage private and government institutions in Chile to cooperate to promote descriptive and experimental research in wind farms to establish adaptive management to reduce mortalities (Arnett et al. 2011; Horn et al. 2008).

Our small sample size does not allow for comparisons to be made across time but it is a necessary step to raise awareness about the potential associated consequences. The species affected have an important ecological role (Kunz et al. 2011). Decrease in bat populations could cause negative ecological and economic impacts in the long term. The fact that only one species was found in the study period, likely reflected the high abundance of $T$. brasiliensis in Chile, its migratory behavior, and the feeding habits at high altitudes in response to insects abundance (Canals \& Cattan 2008; McCracken et al. 2008; Russell et al. 2005). Our ecological niche model provided robust evidence of the plausible patterns of T. brasiliensis geographic range, and demonstrates the broad diversity of climate tolerated by the species (Fig. 4). However, using a less restrictive threshold to generate a binary model, this range may increase. We found that $T$. brasiliensis has one of the broadest distributions for a mammal in the Americas both geographically and environmentally (Fig. 4), which may explain its ecological plasticity and synanthropic behavior. The broad distribution and movement of the species may be related with the early identification of its mortality in wind 
farms in Chile (Fig. 4). The biogeographic isolation of Chile may play a crucial role in the phylogenetic diversity of $T$. brasiliensis (Russell et al., 2005). Thus, complemented with the ecosystem services provided by the species across its distribution may increase its importance for human societies. In fact, Chile appears to host the most southern populations of T. brasiliensis (Fig. 1 and 4).

We highlight two factors to be considered in bat mortality assessment in wind-powered turbines: 1) surveys should be performed before and after installation of turbines to avoid the bias of "low mortality rates by delay," we hypothesize that sustained mortalities in wind farms with a long history of operation may result in a reduction of local bats abundance. Consequently, across years wind farms would show highest mortalities at early stages of operation, but low mortalities in late years of operation. Therefore, low wildlife mortality rates in wind farms with no previous history of surveillance should be interpreted with caution. When surveys in early years of wind farm operation were not possible, the year when turbines started to work should be included in reports; 2) the use of the current nomenclature of death bats/turbine/ year may be a misrepresentation of the damage on large scale wind farms. Instead, mortality by kilometer square or other complementary information, such as number of turbines, could be included considering the extent of the wind farm. However, these factors deserve deeper evaluation.

In Latin America, the fact that these mortality reports are rare is probably the result of the lack of research on the effect of wind farms on wildlife. Strikingly, during the final edition of this manuscript more specimens were found dead in the same areas, but the putrefactive state did not allowed us to perform pathological examinations. Bats found included Histiotus sp., Lasiurus cinereus, and T. brasiliensis (C. Juarez, personal communication). We also highlight the need for further research on the basic ecology of Chilean bats (Iriarte 2007). In South America, future research must summarize migration (or hibernation) patterns, and environmental variables related to mortality on wind farms (Cryan \& Barclay 2009) as the current information regarding these topics are based on data from the northern hemisphere.

Finally, considering the limited access to biological research funding in Latin America, samples from fatalities of bats from wind farms should also be used as a source of information to understand movement patterns, reproductive seasonality, genetics, diet, endocrinology, species distribution, parasites, and other relevant issues to improve bat conservation. Thus, we encourage researchers to consider wind farms in field trips for bat research.

\section{ACKNOWLEDGEMENTS}

Thanks to Renzo Vargas and the Programa para la Conservación de Murciélagos de Chile who encouraged this research. Special thanks to Julia M. Ovalle for her comments on the pathological findings. Emma Stapleton donated an ESRI license, Doug Aitken and Abigail Morrison reviewed the English. Thanks to Huijie Qiao for his collaboration to perform ecological niche models in NicheA. LEE was supported by the Global Emerging Infectious Disease Surveillance and Response System (GEIS) grant P0435_14 UN and Universidad Andres Bello grant DI-412-13/I.

\section{BIBLIOGRAPHY}

Anderson, R.P., Gómez-Laverde, M. \& Peterson, A.T. 2002. Geographical distributions of spiny pocket mice in South America: Insights from predictive models. Global Ecology and Biogeography 11:131-141.

Arnett, E.B., Hein, C.D., Schirmacher, M.R., Huso, M.M.P. \& SzEWCZAK, J.M. 2013. Evaluating the effectiveness of an ultrasonic acoustic deterrent for reducing bat fatalities at wind turbines. PLoS ONE 8:e65794.

Arnett, E.B., Huso, M.M., Schirmacher, M.R. \& Hayes, J.P. 2011. Altering turbine speed reduces bat mortality at wind-energy facilities. Frontiers in Ecology and the Environment 9:209214.

Baerwald, E.F., D’Amours, G.H., Klug, B.J. \& Barclay, R.M. 2008. Barotrauma is a significant cause of bat fatalities at wind turbines. Current Biology 18:695-696.

Barclay, R.M.R., Ulmer, J., MacKenzie, C.J.A., Thompson, M.S., Olson, L., McCool, J., Cropley, E. \& Poll, G. 2004. Variation in the reproductive rate of bats. Canadian Journal of Zoology 82:688-693.

Canals, M., \& Cattan, P. 2008. Murciélagos de Chile. In: Radiografía de los murciélagos de Chile (Eds. M. Canals and P. Cattan), pp. 69-83. Santiago, Chile: Editorial Universitaria.

Cryan, P. \& Barclay, R. 2009. Causes of bat fatalities at wind turbines: Hypotheses and predictions. Journal of Mammalogy 90:1330-1340.

Elith, J., Phillips, S.J., Hastie, T., Dudík, M., Chee, Y.E. \& Yates, C.J. 2011. A statistical explanation of Maxent for ecologists. Diversity and Distributions 17:43-57.

Ellison, L. 2012. Bats and wind energy. A literature synthesis and annotated bibliography. U.S. Geological Survey Open-File Report:57.

Escobar, L.E., Peterson, A.T., Favi, M., Yung, V., Pons, D.J. \& Medina-Vogel, G. 2013. Ecology and geography of transmission of two bat-borne rabies lineages in Chile. PLoS Neglected Tropical Diseases 7:e2577.

Hijmans, R.J., Cameron, S.E., Parra, J.L., Jones, P.G. \& Jarvis, A. 2005. Very high resolution interpolated climate surfaces for global land areas. International Journal of Climatology 25:1965-1978. 
Horn, J.W., Arnett, E.B. \& KunZ, T.H. 2008. Behavioral responses of bats to operating wind turbines. Journal of Wildlife Management 72:123-132.

Iriarte, A.A. 2007. Mamíferos de Chile. pp. 85-93. Santiago: Lynx Edicions.

IUCN. 2014. The IUCN Red list of threatened species. Version 2014.3. < http://www.iucnredlist.org > Cambridge: International Union for Conservation of Nature. Downloaded on 15 November 2014.

Kunz, T.H., Braun de Torrez, E., Bauer, D., Lobova, T. \& FlemING, T.H. 2011. Ecosystem services provided by bats. Annals of the New York Academy of Sciences 1223:1-38.

Kuvlesky, W.P., Brennan, L.A., Morrison, M.L., Boydston, K.K., Ballard, B.M. \& Bryant, F.C. 2007. Wind energy development and wildlife conservation: Challenges and opportunities. Journal of Wildlife Management 71:2487-2498.

McCracken, G.F., Gillam, E.H., Westbrook, J.K., Lee, Y.-F., JenSEN, M.L. \& BALsLey, B.B. 2008. Brazilian free-tailed bats (Tadarida brasiliensis: Molossidae, Chiroptera) at high altitude: Links to migratory insect populations. Integrative and Comparative Biology 48:107-118.

Peterson, A.T., Soberón, J., Pearson, R.G., Anderson, R.P.,
Martínez-Meyer, E., Nakamura, M. \& Bastos, M. 2011. Ecological niches and geographic distributions. pp. 23-95. New Jersey: Princeton University Press.

Phillips, S.J., Anderson, R.P. \& Schapire, R.E. 2006. Maximum entropy modeling of species geographic distributions. Ecological Modelling 190:231-259.

Qiao, H., Soberón, J., Escobar, L.E., Campbell, L. \& Peterson, A.T. 2015. NicheA. Version 3.0. $<$ http://nichea.sourceforge.net/> Kansas: Biodiversity Institute. Downloaded on 10 December 2015.

Rollins, K.E., Meyerholz, D.K., Johnson, G.D., Capparella, A.P. \& LoEw, S.S. 2012. A forensic investigation into the etiology of bat mortality at a wind farm: Barotrauma or traumatic injury? Veterinary Pathology 49:362-371.

Rouby, J.J., Lherm, T., Lassale, E.M. De, Porte, E., Bodin, L., Finet, J.F., Callard, E. \& Viars, P. 1993. Histologic aspects of pulmonary barotrauma in critically ill patients with acute respiratory failure. Intensive Care Medicine 19:383-389.

Russell, A.L., Medellín, R.A. \& McCracken, G.F. 2005. Genetic variation and migration in the Mexican free-tailed bat (Tadarida brasiliensis mexicana). Molecular Ecology 14:2207-2222.

Recibido: 27.03 .14

Aceptado: 18.12 .14 